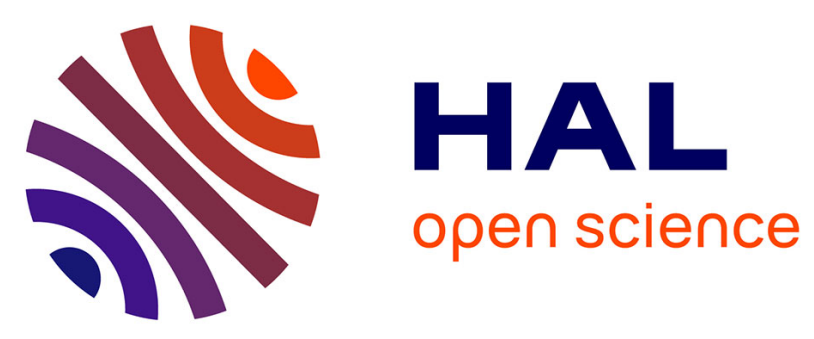

\title{
Citizenship as performance
}

Alain Duplouy

\section{To cite this version:}

Alain Duplouy. Citizenship as performance. Alain Duplouy; Roger W. Brock. Defining citizenship in archaic Greece, Oxford University Press, 2018, 978-0-19-881719-2. hal-02404202

\section{HAL Id: hal-02404202 \\ https://hal-paris1.archives-ouvertes.fr/hal-02404202}

Submitted on 18 Dec 2019

HAL is a multi-disciplinary open access archive for the deposit and dissemination of scientific research documents, whether they are published or not. The documents may come from teaching and research institutions in France or abroad, or from public or private research centers.
L'archive ouverte pluridisciplinaire HAL, est destinée au dépôt et à la diffusion de documents scientifiques de niveau recherche, publiés ou non, émanant des établissements d'enseignement et de recherche français ou étrangers, des laboratoires publics ou privés. 


\title{
Defining Citizenship in Archaic Greece
}

\author{
Edited by \\ ALAIN DUPLOUY \\ and \\ ROGER BROCK
}




\section{OXFORD \\ UNIVERSITY PRESS}

\section{Great Clarendon Street, Oxford, OX2 6DP, United Kingdom}

Oxford University Press is a department of the University of Oxford.

It furthers the University's objective of excellence in research, scholarship, and education by publishing worldwide. Oxford is a registered trade mark of Oxford University Press in the UK and in certain other countries

\section{(c) Oxford University Press 2018}

The moral rights of the authors have been asserted

First Edition published in 2018

Impression: 1

All rights reserved. No part of this publication may be reproduced, stored in a retrieval system, or transmitted, in any form or by any means, without the prior permission in writing of Oxford University Press, or as expressly permitted

by law, by licence or under terms agreed with the appropriate reprographics rights organization. Enquiries concerning reproduction outside the scope of the above should be sent to the Rights Department, Oxford University Press, at the address above

You must not circulate this work in any other form and you must impose this same condition on any acquirer

Published in the United States of America by Oxford University Press 198 Madison Avenue, New York, NY 10016, United States of America

British Library Cataloguing in Publication Data

Data available

Library of Congress Control Number: 2017951885

ISBN 978-0-19-881719-2

Printed and bound by CPI Group (UK) Ltd, Croydon, CR0 4YY

Links to third party websites are provided by Oxford in good faith and for information only. Oxford disclaims any responsibility for the materials contained in any third party website referenced in this work. 


\section{Contents}

List of Figures and Tables $\quad$ ix

List of Abbreviations $\quad$ xi

List of Contributors xiii

1. Pathways to Archaic Citizenship 1 Alain Duplouy

2. State Formation in Early Iron Age Greece: The Operative Forces John K. Davies

3. Retracing Steps: Finding Ways into Archaic Greek Citizenship Josine Blok

4. Citizens and Soldiers in Archaic Athens Hans van Wees

5. Associations and Citizenship in Attica from Solon to Cleisthenes Paulin Ismard

6. Citizenship and Civic Subdivisions: The Case of Sparta Marcello Lupi

7. The Spartan Contribution to Greek Citizenship Theory Paul Cartledge

8. Athletics and Citizenship Nick Fisher

9. Citizenship and Commensality in Archaic Crete: Searching for the Andreion James Whitley

10. Citizenship as Performance Alain Duplouy

11. Oligarchies of 'Fixed Number' or Citizen Bodies in the Making? Maurizio Giangiulio

12. Conclusion: Taking Stock and Looking Backward Roger Brock 


\title{
10 \\ Citizenship as Performance
}

\author{
Alain Duplouy
}

Defining citizenship is a problem that was explicitly stated for the first time by Aristotle in the Politics (3.1275a-1278b). He answered it in a theoretical way by emphasizing the functions and role of the citizen in the political and judicial institutions of the city-state. According to Aristotle, the citizen is 'a man who shares in the administration of justice and in the holding of office' ( $\mu \epsilon \tau \epsilon^{\prime} \chi \epsilon \iota \nu \kappa \rho i ́ \sigma \epsilon \omega s \kappa a i$ á $\rho \chi \hat{\eta} s, 1275 \mathrm{a} 23$ ). By stating this, he explicitly links the duty of citizenship to the offices of judge in the courts and member of the assembly. As outlined in the introduction to this volume (chapter 1), the Aristotelian definition is the product of classical political thought. It arose more precisely in the context of late classical Athens and gave rise to a long scholarly tradition of legal and political studies, which has failed-in my opinion-to provide an accurate account of archaic communities.

Beyond the Aristotelian definition and other philosophical models, it has often been difficult to define archaic citizenship without having the final classical forms as a focal point. The various models of citizenship promoted in the politics of the Athenian classical era (the Cleisthenic, the Periclean, the fourthcentury radical democratic, and the Lycurgan) are so detailed, indeed, that an independent concept of archaic citizenship has never truly emerged in the scholarship. In various aspects, archaic citizenship has therefore been defined in contrast to these classical models, supposed to be more complete, by pinpointing its shortcomings, not by stressing its peculiarities. Such a negative definition led to the idea of an 'incomplete' or 'elementary' citizen status in the archaic period that was still under elaboration. To quote Philip Manville, Athenian citizenship was 'a mere glimmer in the age of Drakon, born under Solon, nurtured by tyrants, and given full form by Cleisthenes. ${ }^{1}$ This kind of statement is actually not very useful in investigating the peculiarities of archaic history. What we are in search of-as inaccessible as it might initially appear-is a definition of archaic citizenship that will be elaborated on positive evidence.

1 Manville 1990, 209. 


\section{ADOPTING AN APPROACH}

Resuming the enquiry where I left it in the introduction to this volume (chapter 1), I shall begin my essay by taking an alternative path arising from Emile Benveniste's linguistic comparison between the two main possible historical accounts of the genesis of the polis. ${ }^{2}$ In short, was the early city a theoretical entity gradually granting 'membership' to its affiliates or was it the empirical result of the 'participation' of individuals in a community in the making? For more than a decade now I have considered the fabric of ancient Greek societies as the product of multiple and continuous relations between individuals, ${ }^{3}$ much more than a process of reforms and revolutions of an institutional model leading from monarchy to democracy. 'Men make the city'

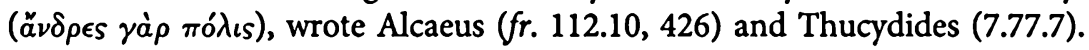
Adopting such a sociological and practical approach also permits us to avoid diverting the issue of an early citizenship to that of the formation of the citystate, as explored by Philip Manville or John Davies. ${ }^{4}$ When asserting the value of individuals and their actions in the process of constructing the polis, I do not refer to the deeds of great men or exceptional individuals, actors of 'History', but to the everyday activities of people living together within a community. In this sense, citizenship should not be conceived as a one-way relation between an abstract entity and its members, but as a web of mutual relationships between individuals, including status recognition processes.

Accordingly, I strongly believe that our understanding of the archaic world could be greatly enhanced by valuing citizenship as a performance, rather than as a granted status enshrined in legal criteria. In the absence of a register certifying one's legal status, the privileges and opportunities of a citizen had to be permanently demonstrated in order to be acknowledged and accepted by the others. Considering how deeply many aspects of the archaic institutions were embedded in social practices, we must lay great stress on the multiple behaviours through which citizenship could be asserted or even claimed. When dealing with the creation and reproduction of the citizen body, Aristotle himself allows the possibility of such a definition: $\tilde{\epsilon}_{\sigma \tau \imath} \delta^{\prime} \dot{a} \pi \lambda \circ \hat{v} \nu^{\circ} \epsilon \dot{i} \gamma \dot{\alpha} \rho$

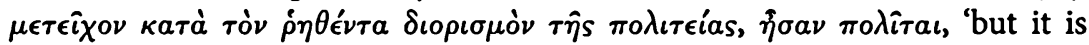
really a simple matter; for if they shared in the politeia in the manner stated in our definition, they were citizens' (3.1275b31-2). As a simple and practical fact, according to Aristotle, those participating in the administration of justice and in the holding of office (metechein kriseōs kai archēs) would be considered as citizens. Nothing more than performing justice and political authority are thus required to account for citizenship, well beyond any consideration of

2 Benveniste 1970; cf. Duplouy 2006b.

3 See the conclusion of Duplouy 2006a, 289-92.

4 Manville 1990, 35; Davies 1996a and this volume (chapter 2) for a more detailed discussion. 
descent. In order to support this assertion, Aristotle brings up the case of the first inhabitants or founders of a city, who of course had no citizen ancestry to justify their own citizen status.

What kind of 'performances' could therefore reveal a citizen status or could be valued as worthy of a citizen? Both collective and individual practices were effective behaviours in asserting or even claiming a citizen status.

Pauline Schmitt-Pantel has long stressed the importance of collective activities such as banquets and hunting in the construction of the 'political' in archaic cities. ${ }^{5}$ She has insisted on the fact that all communal practices were equally significant in the shaping of a political society. More precisely, in archaic Greece, collective activities were not considered as less important than participation in the assembly, which only became the central aspect of citizenship in classical Athens, setting the stage for the Aristotelian model. Their function was to provide equal access to a shared experience, which in turn defined who was a citizen. This anthropological view of the archaic polis is shared by other members of the so-called 'Ecole de Paris'. In placing the emphasis on common cults and religious activities François de Polignac, for example, seminally described the complex mechanism of state formation in early Greece. ${ }^{6}$ More recently, Paulin Ismard has showed that many associations of archaic Athens such as phratries or gene provided a relevant background as well as practical intermediary groups to the construction of an extended citizen community. ${ }^{7}$ Beyond the Parisian sphere Josine Blok has applied this approach to classical citizenship; as she writes: 'without a written administration, the system of recognizing one another as rightful members of a society depended on social connections, control by neighbours and relatives, and shared rites and festivities. ${ }^{8}$ In sum, a wide range of group activities were important aspects of a genuinely archaic definition of citizenship.

As well as collective activities, individual behaviours were also meaningful in the performance of archaic citizenship, at least as far as they complied with the community's shared values. By emphasizing individual behaviours alongside collective activities, I would like to stress that bringing people together in specific spaces (such as the agora, a sanctuary, a necropolis) or at particular times (funeral, sacrifice, meal) is actually not a prerequisite of citizen behaviours. The activities in which citizens participate in common simply do not exhaust the range of shared experiences nor the occasions for the performance of citizenship. The unity of time and space is not necessary to the unity of action in being aware of participating in the community. Repeated individual behaviours reinforce the common values and can therefore create the ties of social cohesion. The system is even self-reinforcing: when there is a growing

\footnotetext{
5 Schmitt-Pantel 1990b; 1998; Schmitt-Pantel and Schnapp 1982. See also Duplouy this volume (chapter 1 , section 5 ).

6 Polignac 1995a. ${ }^{7}$ Ismard 2010; this volume (chapter 5).

8 Blok 2005, 19.
} 
consensus on specific behaviours among the whole community, they tend to be repeated, gradually creating a sensation of homogeneity and a more widespread acceptance. Swiftly, they become the very symbols of participation in the community and consequently constitute distinguishing features between citizens and non-citizens. In this perspective, the notion of habitus, popularized by Pierre Bourdieu's sociology, can be meaningful. Habitus refers to the lifestyle, values, dispositions, and expectations of social groups that are acquired through the activities and experiences of everyday life. According to Bourdieu's own words, they are 'structured structures predisposed to function as structuring structures. ${ }^{\prime}$ They are socially acquired schemata, sensibilities, dispositions, and tastes that are repeatedly reproduced through individual behaviours, therefore reinforcing the strength of the habitus itself. By adopting a particular lifestyle, valued by the whole citizen community, individuals behave in order to be accepted as fellow citizens. Beyond the passive reflection of a collective identity, individual behaviours could also have been efficient strategies to integrate the citizen body, allowing participating outsiders to become more and more recognized as acceptable citizens-to-be. Since participation in collective activities was a way to incorporate people into the group of citizens, adopting the normative behaviours of the citizens in all aspects of one's lifestyle perhaps provided the best means of being acknowledged as a fellow citizen. In short, in order to be accepted as a citizen, one had to behave like a citizen.

Various scholars have already emphasized performance as a key feature in the practice and ideology of the Greek city, and particularly of the Athenian democracy. As Simon Goldhill and Robin Osborne noted in the introductory paper to a stimulating volume, "When the Athenian citizen speaks in the Assembly, exercises in the gymnasium, sings at the symposium, or courts a boy, each activity has its own regime of display and regulation; each activity forms an integral part of the exercise of citizenship. ${ }^{10}$ Since the concept of performance originates from theatre studies, most papers in the volume edited by Goldhill and Osborne deal with the performance of drama in the theatre or speeches in the assembly and public courts. Performing justice and the law is indeed another case in point, exemplified by Vincent Farenga's book on how citizenship and an individual self-awareness were enacted in archaic and classical Greece. To be specific, he defines a series of 'scripts' which enable individuals to negotiate with others for recognition of their personal and citizen status. ${ }^{11}$ On a philosophical level too, performing citizenship has been valued recently in discussing Plato's Laws. ${ }^{12}$ In emphasizing the moral character of the citizenry, Plato's utopian views often equate statecraft with

9 Bourdieu 1977, 72; 1990, 53. See also Duplouy 2014, 657.

10 Goldhill and Osborne 1999, 1.

11 Farenga 2006. See my review in AC 79 (2010), 621-2.

12 Prauscello 2014. 
soulcraft. But if knowing the nature and disposition of the souls are central to the political techne of the stateman, the Platonic ideal state also relates the

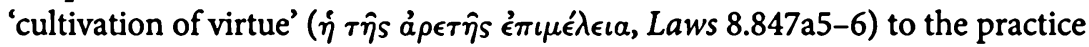
of a good citizen in the second-best city. Accordingly, Lucia Prauscello focuses on how the rhetoric of citizenship is implemented, on a practical level, through specific, ritualized forms of public discourse. In Plato's Laws, the citizens of Magnesia re-enact endlessly their very nature as citizens through collective choral performances. In this sense, Plato was probably promoting what Prauscello calls a 'model of citizenship-as-practice', which represented 'a powerful counter-hegemonic critique of the Athenian normative model of citizenship-as-achievement' grounded in the usual set of formal procedures leading from birth to full membership of the polis. She therefore concludes: 'In Magnesia, citizenship is not-or at least not only-a status or a possession, the once-for-all gained outcome of a given trajectory: it is instead a lifelong practice embedded in the every-day experience of people' lives, with all its changes and transformations through time. ${ }^{13}$

Beyond law, theatre, and political utopia, the concept of performance can be extended to various extant behaviours that were clearly related to the assertion of citizenship. Funerals in classical Athens offer an enlightening example. The dokimasia of the magistrates elected by lot proceeds through the assessment by the Council of the required qualifications and expected behaviours of a citizen. In addition to a citizen ancestry from both parents and the affiliation with a deme and a phratry, the councillors check, among other things, 'whether the incumbent has family tombs and where they are' (Ath. Pol. 55.3). Having a family plot can be intended as common sense, even for foreigners. However, according to Ian Morris' stimulating assumption, in Geometric and archaic Greece burial rights were restricted to citizens alone. As it appears in most cities, only citizens had access to a formal burial (i.e. an archaeologically visible tomb), whereas the non-citizens were excluded from such ritual. ${ }^{14}$ Although an archaeology-based theory, the link between formal burial and citizen status is also documented through various episodes of Athenian history. In temporarily expelling the Alcmaeonidai and their supporters from the Athenian community, Cleomenes and Isagoras also paid attention to the tombs of their ancestors. As Thucydides (1.126.12) reports, 'the living were driven out, and the bones of the dead were taken up'. And it must be remembered that if Themistocles' children brought back their father's bones from Magnesia and granted him a tomb in Piraeus, it was also (if not primarily) to establish their citizenship on their return in Athens. ${ }^{15}$ Stressing the importance of funeral matters in the appraisal of the good citizen,

\footnotetext{
13 Prauscello 2014, 6 and 234-5.

14 Morris 1987. See also Duplouy this volume, chapter 1, section 5.

15 Paus. 1.1.2. See Duplouy 2006a, 69-70.
} 
Aischines (3.77-8) blamed Demosthenes for not having mourned sufficiently and publicly his only child, violating all decency. In highlighting this misbehaviour, Aischines hoped to show that 'the man who is wicked in his individual relations would never be found trustworthy in public affairs'. Examples of such links between funerals and citizen status are numerous in classical authors. ${ }^{16}$ This attention to family tombs or to public lamentation in Athenian politics of the classical era obviously rests on a conception of citizenship based on individual behaviours, which probably goes back to archaic times.

Beyond classical Athens, the performance of citizenship can be documented in archaic cities through specific behaviours. I will discuss here a few examples by strengthening their relation to the assertion or recognition of a citizen status. Despite some similarities, these behaviours were different in each city. Patterns of comportment greatly differ within the archaic world, and practices that were highly valued in some cities could have been deprecated in others. In other words, each city had its own citizen habitus, defining specific behaviours that allowed individuals to be identified as citizens. It should be added nevertheless that probably not all archaic cities complied with this model, whether fully or partially, and that even a performative citizen status could also have been supplemented in some cities with more formal criteria of citizenship. Defining archaic citizenship is definitely not tied to finding a unique and ever-valid standard such as the Aristotelian model of citizenship has promoted.

\section{HORSE-BREEDING}

One of the clearest pieces of evidence linking citizenship status with a particular behaviour in archaic Greece is to be found in Aeolian Cyme. In his epitome of the Aristotelian Constitution of the Cymaians, Heraclides Lembus (second century BC) states (39 Dilts = Arist. fr. 611.39 Rose):

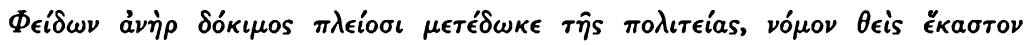

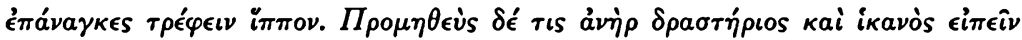

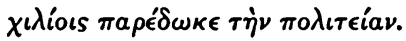

Pheidon, an esteemed man, gave more men a share in the citizenship, establishing a law which compelled everyone to raise a horse. A certain Prometheus, who was efficient and good at speaking, gave to a thousand a share in the citizenship.

In this epitome Heracleides apparently refers to a time immediately posterior to the Persian conquest of Aeolis by Cyrus the Great in the 540s. He reports that Pheidon legislated in order to enfranchise 'more men' ( $\left.\pi \lambda \lambda_{\text {íool }}\right)$, who were 
required to breed a horse. Although the phrasing of the original idea has probably been biased by a fourth-century vocabulary ( $\mu \epsilon \tau \epsilon \in \delta \omega \kappa \epsilon \tau \hat{\eta} s \pi o \lambda \iota \tau \epsilon i a s$, $\nu o ́(0 \nu)$, there is no need to dismiss the primary information on the specificity of citizen status in archaic Cyme.

Before turning to Pheidon, Prometheus' citizenship and its thousand men are worth discussing further. Since we do not know how many horse-breeders benefited from Pheidon's citizenship law, Prometheus' regulation has been variously interpreted: Bürchner originally interpreted it as a restriction, whereas Rubinstein sees it as the inclusion of 'another thousand citizens in the constitution'. ${ }^{17}$ Whatever the number of Pheidonian horse-breeders, the constitution seems to have been fixed-extended or restricted-to a definite number of citizens. According to Clara Talamo, 'ad un certo momento si passa da una costituzione a numero non determinato di cavalieri ad una costituzione a numero chiuso, chiaramente oligarchica'. ${ }^{18}$ Various other cities enjoyed a constitution with a fixed number of thousand men: Colophon, Opous, Croton, Rhegion, and Acragas. This round number has usually been associated with a restricted oligarchy of 'full-citizens'. As Georg Busolt wrote, 'Nur Versammlungen von Körperschaften, die einen Teil der Bürgerschaft umfaßten, nie Versammlungen des ganzen Volkes, werden mit einer bestimmten Zahl bezeichnet. ${ }^{19}$ It is actually quite the opposite. As Maurizio Giangiulio demonstrates in this volume (chapter 11), such round numbers do not actually refer to a privileged subgroup of citizens, an oligarchy within the citizen body, but to the whole body of citizens. ${ }^{20}$ Whether they were 950 or 1,100 at a time, the 'thousand' men probably constituted the quorum or 'symbolic totality' of all the Cymaian citizens. ${ }^{21}$ It is possible that Prometheus simply formalized this entity, giving a name and a simple figure to the citizen body of Cyme, so deserving his description as an 'efficient man'. Such organization and composition of the Cymean citizen body does not rule out Herodotus' reference (1.158.2), in the context of the Persian conquest of Asia Minor, to an Aristodikos son of Herakleides as an $\dot{a} \nu \grave{\eta} \rho \tau \hat{\omega} \nu \dot{a} \sigma \tau \hat{\omega} \nu \dot{\epsilon} \dot{\omega} \nu$

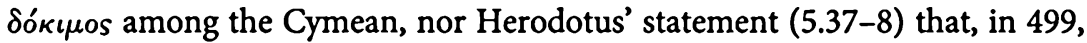
Cyme was ruled by Aristagoras son of Herakleides, for the existence of a fixednumber citizen body is in no way at odds with the existence of an elite.

Whatever the exact purpose and content of Prometheus' subsequent reform, the most interesting feature in archaic Cyme is the link established by Pheidon between horse-breeding and citizenship. It is even likely that, complying with this behaviour, the 'thousand' men of Cyme were themselves

17 Bürchner 1921-2: 'Prometheus beschränkte die Oligarchie auf 1000 Männer'; L. Rubinstein in Hansen and Nielsen 2004, 1043-5.

18 Talamo 1973, 361.19 Busolt 1920, 355 n. 1.

${ }^{20}$ For the 'Thousand of Colophon' mentioned by Xenophanes ( $f r .3$ West), see already Duplouy 2013.

${ }^{21}$ On the notions of quorum and 'symbolic totality', see Gauthier 1990. 
horse-breeders. Of course, it is not possible to state which status or behaviourcitizenship or horse-breeding-had priority over the other, but in practice both were probably interrelated. To apply Bourdieu's own words to the performance of citizenship, the horse-breeding habitus of Aeolian Cyme was probably a 'structured structure predisposed to function as a structuring structure'. The reform would certainly have offered a simple (if not selfsufficient) criterion for enfranchisement: breeding at least one horse-but possibly much more-was the minimum condition to have a share in the Cymaian civic community, therefore strengthening its collective identity. On a very practical level, this behaviour allowed people in the community to identify visually who was a citizen and who was not.

Needless to say, horse-breeding is normally associated with the behaviour of an aristocratic leisure class. As Solon put it in his poetry: 'Happy is he who has dear boys, horse of uncloven hoof, hunting dogs, and a friend in foreign parts' (fr. 23 West). Oswyn Murray made it one of the characteristic features of the aristocratic lifestyle. Breeding and training horses are indeed valued in the context of chariot-racing, celebrated by poets such as Pindar or Bacchylides and thus defined as a 'rich man's sport'. ${ }^{22}$ Beyond any social prestige generally associated with horse-breeding in archaic societies, Heraclides Lembos' epitome of the Aristotelian constitution is however pretty much explicit on the civic value of horse-breeding in Cyme.

More than a social status symbol, horse-breeding was probably in Cyme as in various other archaic cities a military requirement for the citizen army. According to Aristotle's own reconstruction of the past, 'the earliest form of constitution among the Greeks after the kingships consisted of soldiers, and actually in the beginning of horsemen ('ं $\kappa \tau \hat{\omega} \nu i \pi \pi \dot{\epsilon} \omega \nu$ ), for war had its strength

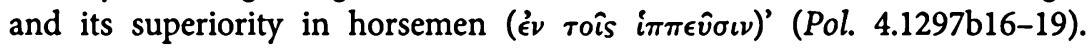
Although well attested for later periods, the existence of cavalry units in the history of archaic warfare is still much disputed. ${ }^{23}$ Of course, the testimonia relating to the First Messenian War and the Lelantine War allude to the use of cavalry as a specific force in early archaic Greece. ${ }^{24}$ Later Greek sources provide, however, suspicious readings of archaic history and are indeed challenged by the total lack of contemporary iconographic evidence. In accordance with the Homeric epics, pictorial representations on Geometric and archaic vases clearly indicate that archaic warriors used their horses principally for transportation as a mounted infantry. Although the existence of fully-fledged cavalry units in archaic warfare remains an issue, horsemen were nevertheless a reality-and a very impressive one-on many battlefields. Horsemanship was undoubtedly related to the military performance of citizenship.

22 Murray 1993a, $204 . \quad{ }^{23}$ Burckhardt 2001.
As emphasized by Worley 1994, 21-58. 
One of the clearest possible examples is provided by two Late Geometric amphoras discovered in Paros and published by Photini Zapheiropoulou. The two Parian vases depict a battle scene with horsemen fighting among chariots and infantrymen. These pots belong to a civic polyandrion probably resulting from the casualties that occurred in a battle between Paros and Naxos during the late eighth century. ${ }^{25}$ Unless we want to identify them with the depiction of a mythological event, these battle scenes probably allude to war casualties affecting the Parian community as a whole. Since the interment in the polyandrion within the context of a public funeral probably did not coincide with the cremation of the dead bodies, which usually happened on the battlefield, these two amphoras could have been commissioned, that is manufactured and painted, after the battle that claimed the lives of the warriors. They were deliberately made to commemorate the deeds of two warriors intended to be honoured with their comrades by a public monument. The content and purpose of the Parian polyandrion predate by at least 250 years the Athenian demosion sema of the classical era. Considering its strong civic tonality, this monument appears to have been the first celebration of the Parian community as a polis. In Geometric Paros horsemanship was thus acknowledged as a major military and citizen achievement.

In sum, what we have in Cyme is not only an elite strategy, but also an individual behaviour explicitly linked to the exercise of citizenship. The citizens of Cyme probably identified themselves as citizens and recognized the citizen status of their fellows through the shared practice of horsebreeding. Other cities in archaic Greece conform to this model.

East Greek cities in general were renowned for their horsemen, so that this model of citizen horse-breeding can perhaps be considered as an Ionian feature. According to Aristotle (Pol. 4.1289b39-40), Magnesia on the Meander belongs to the category of equestrian oligarchies. Aelian (VH 14.46) reports the pair comprising a horseman and a servant carrying a javelin, with the addition of a hunting dog, as a typical Magnesian strategy. The reputation of the Colophonian horsemen was so well established too that, according to Strabo (14.1.28), 'in any obstinate engagement, on whichever side the Colophonian horsemen were auxiliaries, they decided it'. Even the Lydian king Alyattes stood in fear of the Colophonian horsemen, whom he tried to bribe and subsequently slaughtered (Polyaen. Strat. 7.2.2). All these traditions reveal an essential aspect of Ionian warfare. They might also allude to a specific criterion of citizenship, as documented for Cyme, although we lack for these other Ionian cities any explicit link between horsemanship and citizenship.

A more convincing case, where horse-breeding appears as a citizen performance, is offered by the Chalcidian Hippobotai. Although they have been

25 Zapheiropoulou 1999; 2006. See also Croissant 2008b. Amphora no. B3523 is reproduced on the cover by kind permission of P. Zapheiropoulou. 
repeatedly considered as an aristocracy, ${ }^{26}$ the Hippobotai of Chalcis fit well into an archaic definition of citizenship through horse-breeding. There is indeed a strong association between the city of Chalcis and the Hippobotai. Herodotus (5.77), our most ancient evidence on the subject, equated the

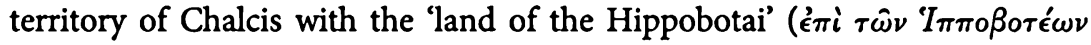
$\tau \hat{\eta} \chi \omega \dot{\omega} p \eta)$, on which Athens settled four thousand klerouchs after defeating the Chalcidians in 506. A similar expression occurs in Aelian (VH 6.1), who refers

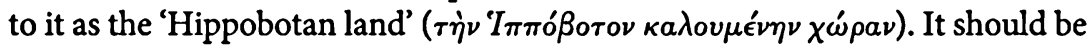
added that during the second half of the sixth century the Chalcidians struck silver coins bearing, respectively, on their obverse facing views of a quadriga (tridrachm), a horseman with a second horse (drachma), and a horseman alone (hemidrachm). These symbols disappeared on coins of the early fifth century, and were replaced on the reverse by a wheel, 'probably an abbreviation for the quadriga of the earlier issues. ${ }^{27}$

Despite this strong civic tonality, the ancient authors normally associated the Hippobotai with oligarchs, and not with the whole citizen body. According to Herodotus (5.77), 'Hippobotai' was the name given to the men of substance

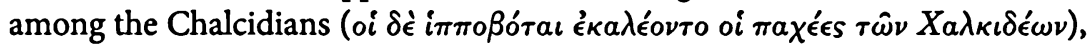
therefore implying that the Athenian kleruchs were given the best lands in the Lelantine plain. This concurs with the (later) Aristotelian taxonomy of an equestrian oligarchy. Aristotle indeed classified Chalcis and Eretria among the poleis of archaic times whose strength lay in their horsemen, used for their wars against their neighbours. Both cities consequently belong to the sort of oligarchy based on wealth and property, such as horse-breeding, for 'it is not easy to rear horses without being rich' (Pol. 4.1289b33-9). This definition was then reproduced by later historians. Explicitly quoting Aristotle, Strabo

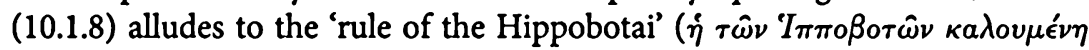

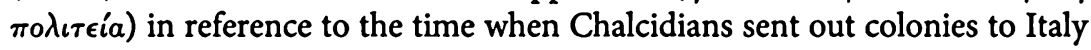
and Sicily in the eighth century. He even defines them as 'a property class

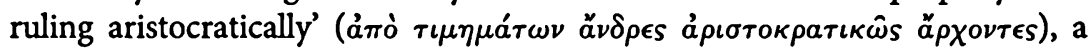
qualification that is obviously an extrapolation based on the Solonian property class of the Hippeis. Finally, Plutarch (Per. 23.4) refers to the Hippobotai as 'those among the Chalcidians who were pre-eminent for wealth and

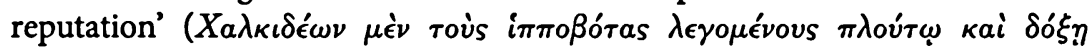

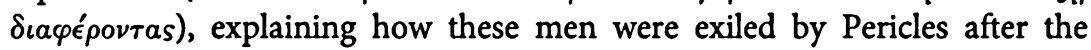
uprising of Euboean cities in 446 and the subsequent re-establishment of Athenian control over Chalcis. ${ }^{28}$

26 See Thalheim 1913; Lazenby 1996; Osborne 1998b; Lubtchansky 2005, 23-6.

27 Kraay 1976, 89-91.

28 The identity of the new settlers, however, remains uncertain. K. Reber, M. H. Hansen, and P. Ducrey, in Hansen and Nielsen 2004, 649 (Chalcis, no. 365) claim that the confiscated land was probably given to 'the other Chalcidians and some foreigners', the former therefore being intended to mean non-elite members of the citizen body in opposition to the Hippobotai. But the 
Despite the recurrent classical and later association between Hippobotai and oligarchs, intended as a subgroup of the whole citizen body, it is tempting to see the Hippobotai as a group of horse-breeders who constituted the whole Chalcidian citizen body. This activity would have been a shared characteristic of the community, and perhaps a formal criterion for participating in it. It looks as if the Chalcidians had adapted the Homeric epithet 'grazed by horses',

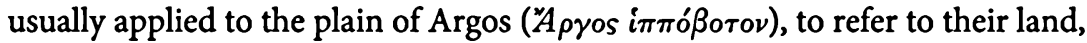
and by extension to the citizens. In precisely the same way Euripides (Or. 1000) named the Argive Atreus hippobotēs, 'feeder of horses', and Pindar (Isthm. 4.14) praised the Theban Cleonymidai for being hippotrophoi. Similarly, Bacchylides (11.114) describes the city of Metapontum as hippotrophos

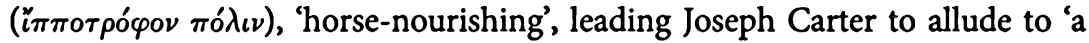
horse-breeding society' for the sixth-century polis. ${ }^{29}$

In classical times the word 'Hippobotai' still referred to the whole polis of Chalcis in expressions such as the 'land of the Hippobotai', but it became mostly associated with an elite of property holders. Do we have to infer that the Hippobotai had constituted by this time a privileged subgroup within the citizen body? It is, of course, possible that citizenship has come to be defined in different ways, so that ownership of horses represented merely a symbol of social status of the sole wealthy members within an enlarged Chalcidian community. But we have to keep in mind that the two major episodes associated with the Hippobotai are related to wars with Athens. In 506 the newly established Cleisthenic regime faced a joint attack by Boiotians and Chalcidians in northern Attica, whereas in 446 Pericles invaded Euboea in order to expel the Hippobotai. One wonders whether the oligarchical definition of the Hippobotai was not actually coined by the Athenians in contrast to their isonomic and democratic regime. As Giuseppe Nenci comments, the

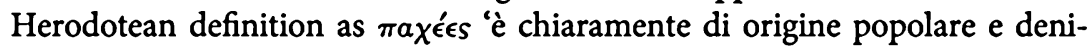
gratoria..$^{30}$ Such a stratagem recalls the analogous denigration of the Spartan homoioi in the context of the Delian League, as well as the subsequent Spartan mirage that has long misled Spartan historiography. ${ }^{31}$ We have to be careful not to reproduce the same error for the Chalcidian Hippobotai. A fully citizen identity could have been turned into a hatred of an elite regime by the Athenians for the sake of political criticism and presented as the ideological justification of a war of subjugation. In archaic Chalcis, horse-breeding was thus probably associated with the performance of citizenship. ${ }^{32}$

establishment of Athenian klerouchs is not unlikely, for at the same time the Hestiaians were removed from their country and supplanted by Athenian settlers (Plut. Per. 23.4).

${ }^{29}$ Carter 1994, $182 . \quad 30$ Nenci 1994, 271.

31 Cf. e.g. Hodkinson and Powell 1994.

32 Other examples of equestrian citizens could be developed (i.e. Eretria, Athens, Sybaris, and Corinth), see Duplouy forthcoming. 
Despite Athenian propaganda, horse-breeding and equestrian duty were the price of citizenship in several archaic cities. They both appear as major elements of citizen behaviour. In these cities men who individually engaged in such activities could reasonably claim participation in the life and values of the civic community. By breeding a horse, the individual was accepted by other community members as a legitimate and honourable partner. Of course, horse-breeding was not necessarily intended as the only citizen requirement and even in these cities other criteria could probably validate the citizenship of an individual or lead to enfranchisement.

\section{PERFORMING LUXURY}

Another example of citizen performance in archaic cities is offered by the various attitudes linked to what we can term 'luxury'. As we will see, performing luxury was not restricted to showing off one's wealth during feasting or processions. In a citizen's life, it was part of everyday experience, as the great diversity of trivial details recorded by ancient authors makes clear for various cities. Of course, we must first clarify the behaviours covered by the notion of 'luxury'.

In modern languages, the word 'luxury' denotes a state of great comfort and extravagant living. It also applies to inessential but desirable objects that are expensive or difficult to obtain. Such a kind of luxury was not highly valued in the ancient world. A great majority of ancient sources portray it as a symptom of moral decadence, while others record a series of sumptuary laws, either in Greek cities or in Rome, designed to curb the display of wealth at funerals. The debate on the private display of wealth and its compatibility with collective interests finds particular resonance in Roman authors. It can be condensed in Cicero's statement (Mur. 36): odit populus Romanus privatam luxuriam, publicam magnificentiam diligit, 'the Roman people disapproves of private luxury, but admires public magnificence'. The same is true for the Greek world, and the critique of luxury, broadly encompassed in the notion of truphe, is a recurring topic in Greek literature and politics. ${ }^{33}$ Although luxury was commonly deprecated in the classical and Hellenistic world, its assessment was however completely different in archaic Greece. Throughout the archaic period, indeed, luxury was a positive quality that was highly prized by poets through the notion of habrosune. As emphasized by Leslie Kurke, habros and its derivatives functioned as 'positively charged markers' throughout the sixth century, even if habrosune had become a 'dirty word' in the fifth

33 Bernhardt 2003. 
century. ${ }^{34}$ Far away from the critics of later times, luxury was actually an accepted lifestyle in various archaic cities. In his seminal study on the legacy of the Eastern world to Greek cities, Santo Mazzarino was probably the first scholar to insist on luxury as an essential feature of the archaic world. According to the Italian historian, habrotēs typified a distinguishing lifestyle, which was learned by the Eastern Greeks from their Oriental neighbours, particularly the Lydians. ${ }^{35}$ Although he then assimilated habrosune with the behaviours of an (old-style) aristocracy, I will follow his path in exploring the topic anew in relation to the performance of citizenship.

A good example of how luxury pervaded the life of archaic citizens is provided by a poem of Xenophanes of Colophon (fr. 3 West). ${ }^{36}$ Xenophanes despises his fellow Colophonians, 'no less than a thousand in general' (ov

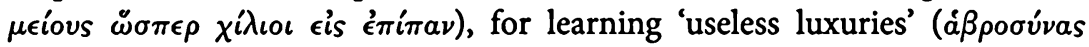
$a \nu \omega \varphi \epsilon \lambda \epsilon a s)$ from the Lydians and going around the agora in purple robes, exulting in the splendour of their hair, and drenched with the scent of the most refined unguents. All these features are commonly attributed to the lifestyle of an archaic aristocracy and Xenophanes' critical tone has been interpreted to allude to the unpopular rule of a hated elite. ${ }^{37}$ As classical and Hellenistic inscriptions show, Xenophanes' allusion to a thousand men rather refers to citizens, and more precisely to all the citizens of Colophon. This group parading in the agora was not a restricted elite, conceived as a privileged subgroup of the citizenry. It represented the entire citizen body, at least on a symbolic level. As further exemplified by Maurizio Giangiulio in this volume (chapter 11), fixed-number communities were not oligarchies in the usual meaning of the word, as Busolt thought (see above, section 2), but political communities in the making. Whatever the reasons for Xenophanes' lament and criticism (probably some bitterness due to his exile), these elaborate manners, sweet perfumes, and wealth were not primarily the symbols of an oligarchy, but key features in the definition of the Colophonian citizen body. Of course, we do not know if there were other criteria for participation in the Colophonian citizenry-without necessarily speaking of legal requirements, as we would expect in a fifth-or fourth-century polis. It is clear, nevertheless, that Xenophanes was describing the standard performance of citizenship in archaic Colophon. These behaviours were probably expected from any individual with the intention of going to the agora, that is attending and speaking at the assembly of Colophon in the presence of his fellow citizens.

34 Kurke 1992.

35 Mazzarino 1947. His book initiated a strong tradition in Italian scholarship on the discussion of archaic luxury, e.g. Cozzoli 1980; Nenci 1983; Lombardo 1983; Ampolo 1984a; $1984 \mathrm{~b}$.

36 For full details of the argument, see Duplouy 2013.

37 Most recently Morris 2000, 184-5. 
This prescriptive attitude is not a Colophonian peculiarity. A similar statement repeatedly occurs for various other poleis, mostly among the Ionian cities and the western colonies in South Italy. One of the best documented examples is the Achaian city of Sybaris, renowned throughout the ancient world for its wealth and the luxurious life of its citizens. ${ }^{38}$ Sybaris ceased to exist in $510 \mathrm{BC}$, when it was razed to the ground by the rival city of Croton. In the search for archaic luxury, Sybaris offers a very interesting case.

Unfortunately, we lack the contemporary evidence of some local archaic poet, such as Xenophanes for Colophon, but the sources are numerous. A large collection of Sybarite stories (logoi sybaritikoi) is known in ancient authors from the fifth century on, and Aristophanes (Wasps 1259, 1427-36) already referred to Sybarite jokes. Sybarite stories were intended as funny and hence enjoyed a long popularity. Apart from a few sentences in historians (Herodotus, Strabo, and Diodoros), the bulk of our information comes from antiquarian literature, mainly from Athenaios. Book 12 of the Deipnosophistai, which is entirely devoted to luxury, includes a large section on the Sybarites $(518 c-522 a)$ full of improbable and burlesque anecdotes. The sources are not easily interpreted, but they should not be dismissed as mere comical tales, even if few stories can be traced back to a classical author in order to assess the degree to which they have been modified by later writers. A notable exception is the story of Smindyrides of Sybaris, one of the wooers of Agariste of Sicyon. Herodotus (6.127) already presents him as 'the most luxurious man of his day ( $\left.\dot{\pi} \pi i \pi \lambda \epsilon \hat{i} \sigma \tau o \nu \delta \dot{\eta} \chi \lambda_{\iota} \delta \hat{\eta} s\right)$ at a time when Sybaris was at the height of its prosperity'. Other details were subsequently added by later authors (from Timaios to Aelian) who greatly exaggerated this story by having Smindyrides travel to Sicyon with a thousand cooks, and as many fowlers, fishermen, and slaves. ${ }^{39}$ The basic elements of the story and the overall impression might be accurate, but the numbers were certainly inflated. If these anecdotes were amplified through time and if their perspective, as we will see, was re-elaborated by later authors, the opulence of archaic Sybaris and its citizens is certainly not an invention.

In order to extract with confidence a distinctive Sybarite lifestyle out of these folk tales, our sources have to be subjected to a strict criticism. Overall, two layers of further elaboration are clearly discernible: a Crotoniate hostile perspective (initially late archaic and classical) and a moralizing disapproval of luxury (typical of Hellenistic and Roman times), both resulting in a strongly negative presentation of archaic Sybaris intended as a kind of 'sin city'.

A significant part of the tradition about Sybaris concerns the city's feud with its neighbour and enemy Croton, which eventually annihilated it in 510 .

38 See Callaway 1950.

39 See Athen. 6.273b; $12.541 \mathrm{c}$ (quoting Timaios); Ael. VH 12.24. Note that Plato (Symp. 197d) makes $\chi \lambda_{i} \delta \dot{\eta}$ a synonym of $\tau \rho v \varphi \eta^{\prime}$ and $\dot{\alpha} \beta \rho \rho^{\prime} \tau \eta$ s. 
Accordingly, our sources often reproduce a distorted vision of the events promoted by the victor. It is not the place here to survey the chain of events that led to the complete destruction of Sybaris. ${ }^{40}$ It will be sufficient here to state that Pythagoras' move to Croton in about $\mathbf{5 3 0}$ had serious consequences for Crotoniate politics, leading to the establishment of a regime based on esoteric philosophy and radical austerity in citizen lifestyle, both promoted as conducive to good government and civic virtue. After the battle of the Sagra, which resulted in a severe defeat against the Locrians, Pythagoras invigorated the low morale of the Crotoniates by promoting an ascetic attitude to life and citizen duty. It could only be opposed to the luxurious Sybarite lifestyle which the Pythagoreans probably overstated and amplified. ${ }^{41}$ Many Sybarite stories hence establish a strong contrast between the two ways of life. For example, the Sybarites were said to be averse to any type of manual work, so that they could not understand why, in a city of such importance, Crotoniate athletes were supposed to prepare and dig up the ground of the palestra themselves (Athen. 12.518d). The opposition also extended to sacred matters. According to the Crotoniates, the Sybarites infuriated the gods by their repeated acts of impiety, such as murdering the thirty ambassadors from Croton or slaughtering the supporters of the tyrant Telys who had sought refuge at the steps of the gods' altars (Athen. 12.521e-f). From a religious point of view, a war against Sybaris was thus both necessary and justified, so that the complete destruction of a sinful city appeared as a legitimate divine and human retribution. If further elaboration by later Pythagoreans is not impossible, the core of the tradition on the rivalry between Sybaris and Croton certainly originated in the immediate aftermath of the war. The Crotoniate Pythagoreans had to substantiate their extreme deeds. Formulated to the disadvantage of the Sybarites, these logoi were mainly used by the Crotoniates for the purposes of propaganda.

This inverted mirror does not, however, preclude any plausibility as to the reported Sybarite lifestyle. Indeed, if the Pythagoreans elaborated an image of Sybaris as the ultimate anti-polis, Croton had itself become a kind of countermodel under their leadership. In rejecting a meat diet and the sacrifice as an essential link between the community and the gods, the Pythagoreans also turned their back on the cornerstone of the Greek polis. This also explains the unusual severity of the defeat inflicted upon the Sybarites, which is unprecedented in Greek history: all prisoners were slaughtered, the city was razed to the ground, and the ruins were flooded by the diversion of the river Krathis. The extreme character of this type of war involving annihilation contradicts the more usual hoplite tactics with their moderate casualties. ${ }^{42}$ In every

40 Dunbabin 1948, 359-65; De Sensi Sestito 1984, 32-51.

41 Talamo 1987; Ampolo 1993; Bernhardt 2003, 51-7.

42 Ellinger 1993, 187-95. 
respect, the Pythagorean Croton itself appears as an anti-polis, and Sybaris is perhaps more the anti-Croton than an unusual archaic city.

Beyond the Pythagorean propaganda, the fate of Sybaris came to be regarded as the consequences of an excess of luxury. This principle of historical causation is well attested in Hellenistic historiography, ${ }^{43}$ and as early perhaps as the classical period (see Hdt. 1.155). The concept of truphe, which arose during the fifth century as a characteristic feature of Oriental people, was perceived as having debilitating effects on both individuals and cities. It was a symbol of hybris and decadence. ${ }^{44}$ It first offered a behavioural explanation for Persia's defeats in 490-479, but the perspective was subsequently extended to all Barbarians and to various Greek cities. Timaios of Tauromenion, who wrote extensively on Sybaris (according to the various quotations of his work in Athenaios), complied with this idea, as did Strabo: $\dot{v} \pi \dot{o} \mu \epsilon \epsilon^{\prime} \tau o \iota ~ \tau \rho v \varphi \hat{\eta} s$

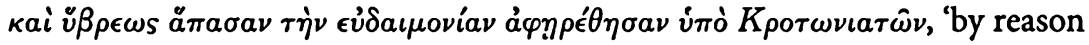
of luxury and insolence they were deprived of all their felicity by the Crotoniates' (6.1.13). From prosperity (eudaimonia) and unrestrained ostentation (truphē) to arrogance (hubris) and destruction, the story of Achaian Sybaris was supposed to illustrate a general scheme. An even stronger moral perspective then appeared in Athenaios' Deipnosophistai, who stamped truphe as a strongly negative and reprehensible behaviour. Again, Sybaris was castigated as a 'sin city' that deserved a place in the hall of fame of corrupted nations, which would be Book 12 of the Deipnosophistai.

However, the condemnation of luxury and the idea, whether historical or moral, that luxurious living brings on ruin are anachronistic conceptions when applied to the history of Sybaris. As already noted, throughout the archaic period, luxury then termed habrosune was a positive quality. In this sense, the Sybarite way of life simply echoes Sappho's pragmatic and unashamed statement $\tilde{\epsilon}^{\prime} \gamma \omega \delta \dot{\epsilon} \varphi \hat{\prime} \lambda \eta \mu \mu$ ' ả $\beta \rho o \sigma u ́ v a v$, 'I love luxury' (fr. 58.25 LobelPage) or Solon's verse which equates $\dot{\alpha} \beta \rho \alpha \dot{\alpha} \pi a \theta \epsilon \hat{\imath} \nu$ to riches and comforts in food and dress (fr. 24.4 West). It also echoes the luxurious lifestyle of the Lydians, praised by so many of the lyric poets: Sappho extols elaborate Lydian dress items (fr. 39, 98 Lobel-Page), while Alcman celebrates the luxury of a Lydian wimple (fr. 1.67-8 Campbell) and contrasts the country boors of Thessaly to a 'man of highest Sardis' (fr. 16 Campbell).

Overall, the critical tone that has subsequently shaped the whole tradition about Sybaris is therefore inappropriate for an approach to archaic behaviours. Despite the biased perspective of our sources, the luxurious lifestyle of the Sybarites is not to be challenged. Beyond the unavoidable historiographical

43 Passerini 1934; Schepens 2007, 258-61. Contra Gorman and Gorman 2007 and, more generally, Gorman and Gorman 2014, who ascribe the whole perspective to Greek authors of the Roman period, such as Athenaios.

${ }^{44}$ Hall 1989. 
discussion, Sybarite luxury has thus to be valued historically. According to the Sybarite stories, it probably extended to all aspects of individual and social life: elaborate purple dress, sophisticated food, endless feasting, much sought-after tranquillity and easy life, and so on. Even the most fanciful tale can allude to an existing although distorted behaviour.

Quoting Aristotle's lost Constitution of the Sybarites, Athenaios (12.520c) reports that 'they had carried their luxurious refinement to such a point that their horses were accustomed to dance to the flute even at their feasts'. The Deipnosophist then relates how their Crotoniate enemy took advantage of this custom by playing a tune on the battlefield and how the Sybarite horses danced away the battle. What seems to be a 'good after-dinner story ${ }^{35}$ reveals the existence of a highly skilled 'cavalry' trained to perform specific figures. ${ }^{46}$ Selective breeds were developed in sixteenth- and seventeenth-century Europe, such as the Lipizzaners of the Spanish Riding School of Vienna. Classical dressage movements and training, whose principles are based on the writings of Xenophon, were intended to prepare powerful and agile horses not only for parade, but also and more specifically for warfare. It was highly fashionable in the nobility of modern Europe, and kings and princes spent considerable resources to provide their army with such practised units. It is likely that dressage also existed in archaic Greece: we clearly see it, for example, on a Protoattic oinochoe. ${ }^{47}$ Highly skilled horses suppose a collective involvement. Accordingly, the so-called refinement of the Sybarite behaviours probably refers to the existence of intensively trained horsemen, as it could be part of a citizen education. There is indeed more reference to such tutelage.

According to Athenaios (12.519c), 'the horsemen of the Sybarites, more than 5,000 strong, paraded with saffron-coloured coats over their breastplates, and in summer their young men (oi $v \in \dot{\omega} \tau \epsilon \rho o$ ) journeyed to the Caves of the Nymphs on the Lusias river and there spent time in every form of luxury'. The neōteroi's summer retreat to a sanctuary of the Nymphs is strongly reminiscent of some kind of initiation rite for citizens-to-be. More specifically, the word $\nu \epsilon \dot{\omega} \tau \epsilon \rho \circ$ is probably a rephrasing of an actual age group within the archaic Sybarite society that was later equated with the late classical and Hellenistic ephebic institution. It becomes obvious indeed that some sort of citizen education is implied when considering this other story reported by Athenaios (12.518e): 'It was customary also among the Sybarites for the boys until they reached the age of young manhood ( $\tau$ ov̀s $\pi a \hat{\imath} \delta a s \mu \mu^{\prime} \chi \rho \iota \tau \hat{\eta} s \tau \hat{\omega} \nu \dot{\epsilon}^{\prime} \varphi \eta^{\prime} \beta \omega \nu$ i $\lambda_{\text {ckias) }}$ to wear purple cloaks and have their hair tied up in braids secured by gold ornaments.' Athenaios' source could be Timaios of Tauromenion, whose quotations are recurrent in his Sybarite account. Having spent most of his life in

45 So Rutter 1970, $170 . \quad 46$ See Lubtchansky 1993; 2005, 43-69.

47 Papadopoulos 2006, 132-3, fig. 125 A-C. 
exile in Athens, Timaios probably applies to the Sybarite youth the names of the corresponding Athenian institutions. The words paides and ephéboi could therefore allude to the existence of age groups of young men trained as soldiers and destined to become citizens.

The two stories insist on the luxurious dress of these men, which is clearly defining of a Sybarite habitus. Incidentally, both the parading horsemen with their saffron-coloured coats and the young men with their purple cloaks are reminiscent of the Colophonian citizens going around the agora. Again, the citizen tone is nothing but explicit in this lavish and imposing performance. As has been insistently noted by various Italian historians, ${ }^{48}$ it must be stressed that in the archaic period the idea of luxury (habrosune) was not conceived as an individual eccentricity, but as a shared value, as a collective ethos. If several individuals, such as Smindyrides, are singled out for their manners, it is also as typical representatives of their city. We are thus not only dealing with an ethic of individual achievement allowing the establishment of ranks among the citizens, but with a general trend towards conspicuous consumption as the distinctive expression of a community lifestyle. Sybarizein ('living like a Sybarite'), which is attested as early as Aristophanes (Peace 344), denotes a way of life associated with the city of Sybaris as a whole. As Mario Lombardo emphasizes, in archaic Greece, habrosune was not a strictly elitist behaviour; it pertains rather to a large community. To what extent then could it be considered the foundation of a specific model of archaic citizenship?

According to Athenaios, there were 'more than 5,000 horsemen'. If not exaggerated, this figure would represent a very large number of Sybarite horsemen. Considering the strong citizen connotation of horse-breeding and citizenship in Sybaris as in other archaic cities, this figure could also represent the entire citizen body of the Sybarites. Is it enough? Of course, by comparison with the 50 or 60,000 adult male Athenian citizens in $431,{ }^{49}$ this would appear as a very restricted and oligarchical citizenry, which is reminiscent of the Athenian regime of the Five Thousand called into being to replace the Four Hundred in 411 BC. Again, reading archaic history into the tracks of classicaland especially classical Athenian-history is misleading. Five thousand citizens, whether or not on a symbolic level, would nevertheless make Sybaris a very strong and populous archaic city, five times for instance the size of Colophon. By the way, in Sybaris, horsemanship may have been only one among many other behaviours linked to a citizen status.

Other figures of the Sybarite citizen body are known from ancient authors. Diodoros of Sicily (12.9.1-2) gives the figure of 300,000 citizens, which

48 See esp. Lombardo 1983; Nenci 1983.

49 Due to the plague, war casualties during the Peloponnesian War, and the siege of $405 / 4$, the number of citizens dropped to some 25-30,000 in c.400. On the number of Athenian citizens, see Rhodes 1988, 271-7; Hansen 1988, 14-28. 
corresponds to the number of men reportedly brought together against Croton in 510, as stated by both Strabo (6.1.13) and Diodoros (12.9.5). The latter adds that the Crotoniates were (only) 100,000. Pseudo-Skymnos (340) gives the figure at close to 100,000 astoi for Sybaris. Though probably overestimated, these numbers should not necessarily be dismissed as 'inhabitants' rather than 'citizens'. However, it must be acknowledged that two levels of political affiliation are actually conflated in these figures: the Sybarite citizen status and the Achaian ethnic identity, both referred to in Diodoros by the word politai. As has been convincingly argued by Emanuele Greco and Carmine Ampolo, these figures should indeed be set against Strabo's statement (6.1.13) on the large empire of the Sybarites, who exercised their hegemony over four tribes and twenty-five cities. The number of 300,000 citizens may therefore refer to the Sybarites and their allies. ${ }^{50}$

Regarding the nature and extent of Sybarite citizenship, Diodoros' text (12.9.1-2) is worth quoting in full, for it reveals a very unusual feature for a Greek archaic city:

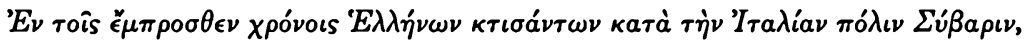

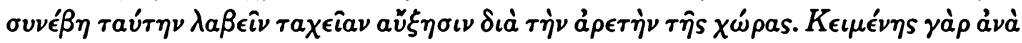

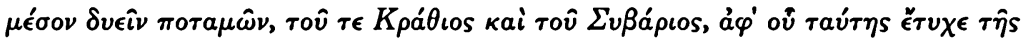

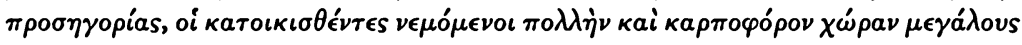

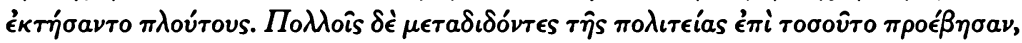

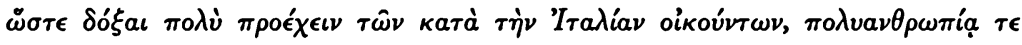

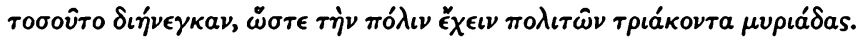

When in former times the Greeks had founded Sybaris in Italy, the city had enjoyed a rapid growth because of the fertility of the land. For lying as the city did between two rivers, the Krathis and the Sybaris, from which it derived its name, its inhabitants, who tilled an extensive and fruitful countryside, came to possess great riches. And since they kept granting citizenship to many people, they increased to such an extent that they were considered to be by far the first among the inhabitants of Italy; indeed, they so excelled in population that the city possessed 300,000 citizens.

The ancient historian is highlighting three significant elements: a) the fertility of the Sybarite territory, in terms of both land and rivers; b) the ensuing prosperity of its inhabitants; and c) the large extent of the citizen body. The first two characteristics are common knowledge in Sybarite stories ${ }^{51}$ and are related to various other ancient states as well. ${ }^{52}$ The third and last point is an

50 Greco 1990; Ampolo 1993, 242-4. See also Papadopoulos 2002, 26.

51 For a comic version of the fertility of the rivers, for example, see the extract of Metagenes' play The Thurio-Persians as quoted by Athenaios (6.2691).

52 See Athen. $12.526 \mathrm{f}$ (Umbrians), 527e (Syrian cities), and 528a-b (Capua), quoting respectively Theopompos (FGrHist 115 F132), Poseidonios (FGrHist 87 F10), and Polybios (7.1.1-3). See Ampolo 1984b, 474. 
interesting statement of the Sicilian historian. Although linked to the 300,000 citizens and allies within the Sybarite empire, the liberality of the Sybarites in granting citizenship appears to Diodoros as an essential feature of the Sybarite identity, worthy of being singled out. To say the least, this generosity was contrary to the usual restraint shown by most classical Greek poleis. To fully understand Diodoros' statement, we must indeed remember the contrast drawn by Philippe Gauthier between 'Roman generosity' and 'Greek avarice' in the granting of citizenship. ${ }^{53}$ This behaviour was also contrary to most of the Greek colonies in the Western world (with the exception of course of Cyrene under the reign of Battos II, cf. Hdt. 4.159).

Focusing on the extent of the citizen body in the Greek cities of Southern Italy, Benedetto Bravo asks this simple question: what was the judicial status of those who, being free men, settled in a colony without being invited to do so after the initial stage of the foundation, that is after the original distribution of the land? In answering this question, he distinguishes two very different concepts of the citizen body in the Western colonies. In most of the Greek poleis, such as Syracuse, the original settlers and their descendants long remained a closed group that alone enjoyed citizenship, while many free men were simply denied the citizen status and all attendant rights such as the possession of land. On the contrary, the liberality of the Sybarites means that the city kept granting the citizen status not only to additional settlers coming from Greece but perhaps to some native Italians as well. ${ }^{54}$

In linking this liberal citizenship policy with the great riches derived from the land, Diodoros is implicitly establishing a relationship between wealth and citizen status. This does not mean that the Sybarite citizenship was primarily based on property qualification. In a city renowned for its lavish level of expenditure in every aspect of individual and social life, the acknowledgement of a citizen status by the members of the community could rather be tied to the performance of luxury, which had become a prescriptive pattern of Sybarite lifestyle. Multiple behaviours modelled on the shared value of luxury would then be of primary importance in the admission into the Sybarite citizen body. The fact that great riches were the common fate of many Sybarite citizens can be paralleled with Aristotle's statement about Colophon. The Stagirite (Pol. $4.1290 \mathrm{~b}$ ) notes, as an unusual feature for a Greek city, whether a democracy or an oligarchy, that the wealthy Colophonians were in greater number than the poor. In both Sybaris and Colophon, the performance of citizenship was strongly related to the practice of habrosune, which itself could be associated with what I term in the first chapter of this volume (chapter 1 , section 3 ) an 'economy-driven citizenship'.

53 See Gauthier 1974; Cartledge this volume, chapter 7.

54 Bravo 1992, esp. 44 and 82. 
Conversely, various behaviours were probably inconsistent with a citizen status, that is with the luxurious and quiet life of the Sybarites. As Athenaios $(12.518 \mathrm{c}-\mathrm{d})$ reports, 'the Sybarites were the first to forbid noise-producing

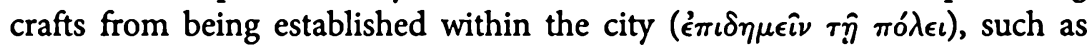
blacksmiths, carpenters, and the like, their object being to have their sleep undisturbed in any way; it was not permitted even to keep a cock inside the city'. This banal Sybarite joke can probably be best interpreted in the light of Aristotle's general theory (Pol. 3.1278a) of the occasional exclusion of craftsmen (banausoi) from citizenship. ${ }^{55}$ Whereas Aristotle associates this exclusion with a lack of virtue (aretē), artisans having no knowledge or practice of the value of a good man, the Sybarites conceived it as a disturbance to their lifestyle, even if some details are clearly later ad hoc additions for the sake of the joke. Not only did they forbid them to reside in the city, but they probably also excluded them from citizenship on behavioural grounds. Note indeed that the verb $\epsilon^{\prime} \pi \delta \eta \eta \epsilon^{\prime} \omega$ is commonly associated with foreigners, that is non-citizens. ${ }^{56}$

In sum, luxury and its performance seem to offer a very sound model of archaic citizenship, although it might appear-at least by classical stand$\operatorname{ards}^{57}$ as a singular one. But it was certainly no oddity. Let us remember that Thucydides (1.6) opposes two very different ways of life (diaitai): an old one, to habrodiaiton, enshrined in luxury (such as linen undergarments and golden hair clips), which used to be common among Ionian people, and a more modest style of dressing, more in conformity with contemporary ideas, which was first adopted by the Lakedaimonians and then, after the Persian Wars, by the Athenians. Obviously, Sybaris belonged to the first category; hence the various Sybarite stories that stood in contrast to Spartan values. ${ }^{58}$ Ultimately, this lifestyle can also be traced back to the enjoyable life of the Homeric Phaiakians (Od. 8.248-9), which has certainly offered to various Greek cities a desirable model to match.

As an alternative to the classical model of (Athenian) citizenship, as promoted by Aristotle and a long tradition of political and legal studies since the nineteenth century, a performative approach to citizenship, as exemplified through Colophon or Sybaris, certainly offers a stimulating pathway into archaic history. As Carmine Ampolo wrote, in fin dei conti ripensare oggi Sibari vuol dire ripensare l'arcaismo e la polis arcaica'. ${ }^{59}$

55 On the different cases, see Lévy 1979.

56 Cf. Xen. Mem. 1.2.61; Lys. 12.35; etc.

57 See, however, Miller 1997, 188-217 on the real place of 'luxury culture' in classical Athens. See also Villacèque 2008. Note also the request of the chorus of Aristophanes' Knights for tolerance of their lifestyle, though by this date it was only sectional.

${ }^{58}$ Cf. Athen. 4.138d; 12.518e. ${ }_{59}$ Ampolo 1993, 254. 


\section{CITIZENS AS ELITES}

The examples discussed here show that in various archaic poleis citizenship appears to have been conceived as a performance, more perhaps than as a granted status enshrined in legal criteria. In searching for a shared experience, individuals established a set of common values and behaviours, whether collective or individual, that soon became patterns of civic identity allowing them to distinguish between insiders and outsiders.

This challenging model of archaic citizenship as a performed status entails a further analogy with the elite status. Of course, the behaviours discussed here (horse-breeding and luxury habits) can be stigmatized as (mere) elite behaviours. For sure also, archaic citizens were an elite vis-à-vis non-citizens. But, on a more fundamental level, the nature of citizenship and the structure of the citizen body were closely related in some archaic cities to the way the elite could be defined, without automatically equating one with the other.

As I demonstrated in my book Le prestige des élites, the old notion of a nobility ruling archaic cities and enjoying a life of pleasures thanks to their riches, as a kind of leisure class, is both obsolete and irrelevant so far as the extant sources are concerned. ${ }^{60}$ Conversely, honour and social esteem were key patterns in the construction of a social hierarchy. In most ancient Greek cities, rather than being ascribed or inherited, the elite status was mostly achieved through a constant investment in time-, money-, and energyconsuming practices, such as stating a genealogy, negotiating a marriage, collecting world artefacts, erecting monumental offerings, and so on. Depending on the local circumstances, there were countless opportunities to show, maintain, enhance, or acquire an elite status in most archaic poleis.

As I argue here, behaviours were also of primary importance in achieving a citizen position within a community. Taking part in a public festival, feasting with fellows, training with a view to military engagements, but also breeding horses or complying with the global image of the polis through an ostentatiously lavish lifestyle were essential behaviours that could be expected from citizens or would-be citizens, and perhaps even from aspiring citizens. These 'citizen strategies', as I would term them, were not only demonstrative behaviours on the part of enfranchised citizens, but also potential tools used by candidates for a citizen status. They were part of a distinctive 'citizen habitus'. The essential points in this concept of archaic citizenship are the civic recognition and the social acceptance by fellow members of the community. Embracing the behaviours of the citizens was perhaps the best way to be acknowledged as a citizen. This means that in some archaic cities, citizenship

${ }^{60}$ Duplouy 2006a. Now Fisher and van Wees 2015b. Contra Stein-Hölkeskamp 1989. 
was defined-at least in part-as elite status was, that is through a constant investment in public strategies of recognition.

In this sense, both elite and citizen statuses would have been constructed through behaviours. Is there any difference, therefore, between what we would call 'citizen strategies', on the one hand, and 'elite strategies' on the other? And, if they are contrasting behaviours, what is the nature of their differences? How much would performing as a citizen be distinct from performing as an elite?

For the past two decades, Ian Morris has offered a simple answer to all these questions by promoting a dichotomous model of ancient societies. ${ }^{61}$ According to Morris, archaic history is best understood as a conflict between two antithetical cultures: the middling ideology and the elitist ideology. The elitist ideology reinforced solidarity within an international aristocracy through common values of excellence. It was the cement of a group that 'wanted to fashion itself as a ruling class by claiming to monopolize a high culture beyond the reach of the masses'. The elitist tastes mainly include the heroic past and heavenly luxury, the east and Orientalizing goods, the symposium and interstate games, foreign friendship and hospitality, all symbols of undisguised superiority over the mass of moderate (and poor) citizens. It was a class phenomenon. Likewise, the middling ideology was 'a class- and genderbased ideology, working in the interest of the less well-off men but leaving room for others to use it for their own ends'. Although theorized by educated men, this ideology was at the roots of what the American political theorist Robert Dahl terms the 'Strong Principle of Equality', ${ }^{62}$ which allegedly led to the establishment of democracies in the classical world. According to Morris, the salient features of the ideal middling men (hoi metrioi or mesoi) are already perceptible from the eighth century. Even if they were not constituent of a Mittelschicht, the middling men were nevertheless intended by archaic poets as self-sufficient farmers. More precisely, they were part of an ideological construct, allowing all citizens, regardless of their wealth, to locate themselves in the middle (to meson) if they chose to do so. In this sense, even the archaic authors can be distinguished according to their attitude: Homer would thus stand at the head of the elitist ideology, Hesiod in the middling. Around 500, however, elitism collapsed and the middling ideology eventually prevailed, steering for the democratic revolution of the classical city. Yet, these antithetical cultures remained a matter of political dissent between the dèmos and an elite of birth, wealth, or education throughout the classical period.

Such a reconstruction of the archaic world originates from two major biases: first, there is a backwards reading of the classical middling ideology

${ }^{61}$ Initially presented in Morris 1997 and fully developed in Morris 2000. Quoted hereafter is Morris 2000, 163 (elitist) and 119 (middling).

62 Cf. Dahl 1989; Morris 1996. 
into archaic texts; second, an extension to the whole Greek world of a primarily Athenian construct regardless of historical developments in other cities. In Morris' work, the theorization of a middling ideology rests on a preliminary study of the speeches delivered in law courts, political assemblies, and public funerals in classical Athens, not to mention the dramas performed in state festivals and the philosophical treatises. It is then perhaps not a surprise that Morris' theoretical model of a dichotomous archaic culture is in fact extremely close to the perspective elaborated by Josiah Ober on classical Athenian society. Ober imagines Athenian political history as the product of a long-standing opposition between the mass of citizens and the elite, as a struggle arising from a conflict between aristocratic values and demotic sensibilities. ${ }^{63}$ To put it briefly, Morris' view of the archaic world, explicitly and deliberately elaborated from a fourth-century perspective, offers a convincing prequel to Ober's historical account of classical Athens. Though perfectly coherent, this comprehensive model of Greek history, as reconstructed by various historians, nevertheless draws on a circular argument, for it fails to produce an independent and critical view of archaic history. Filling in earlier periods of cultural history by analogy to later literature almost always stresses formal continuities and reinforces a questionable picture of a historical linear development. Such a teleological approach is definitely not the best way, pace Morris, to pursue what Foucault castigated as the 'chimera of origins'.

Despite early and thorough critics, ${ }^{64}$ such a model of the archaic world has flourished in recent scholarship. Yet the existence of a so-called 'middling ideology' in the archaic period is little more than a chimera. Besides methodological dissent on a backward-looking exegesis of archaic texts, I strongly argue in favour of a Greek society wholly nurtured by the culture of competition. ${ }^{65}$ The agonistic mentality is certainly one of the most significant features of ancient Greek civilization: 'always be the best and be superior to others' is a Homeric principle $(I l .6 .208 ; 11.784)$ that enjoyed a wide currency. The values of competition were treasured by many people throughout time regardless of one's position in the social spectrum. Both the elite and the 'common people' shared the same agonistic mentality, for it was an essential feature in the recognition of the former by the latter. According to Nicole Loraux, even the most distinctive performance of the Athenian democracy, the funeral speech (epitaphios logos), was deeply rooted in an agonistic culture. ${ }^{66}$ Simply put, the ancient Greek city was not schizophrenic.

63 Ober 1989; 1998.

64 Hammer 2004; Kistler 2004. Hall 2014, 178-82 and Osborne 2009, 354 are also highly critical of Morris' decontextualized reading of archaic texts.

${ }_{65}$ Duplouy 2006a, 271-82. There are of course strong regional and individual variations in the diffusion of this agonistic culture.

${ }^{66}$ Loraux 1986, esp. 95-6. 
So, what could be the difference between 'citizen strategies' and 'elite strategies'? Rather than being juxtaposed, the two concepts are closely related. As concerns the nature of their discrepancy, it might be quantitative rather than qualitative. Even if no specific lower limit can be established to both citizen and elite statuses in every case, the difference between them may be closer to successive degrees on a scale. 'Citizen strategies' and 'elite strategies' were thus not conflicting, but supplementing behaviours in the same process of an individual self-achievement. From a certain level of social investment, which varied from one city to another depending on the shared values, a citizen behaviour could turn into an elite strategy. The same practice could then embrace both dimensions. There has been a long discussion on the nature of the archaic symposion in order to decide whether it was an elite (Murray) or a citizen strategy (Schmitt-Pantel). ${ }^{67}$ Depending on which aspect each city put the emphasis on, it helped to define either an elite within the citizen body or the citizen body itself-which was, as already noted, an elite vis-à-vis non-citizens. To return to Aeolian Cyme, breeding one horse was clearly a criterion for citizenship, whereas having several horses was probably a matter of pride among the citizens. And of course, having more than one horse was not necessarily considered as an anti-polis attitude. Elites were also-and primarily-citizens, while not all citizens belonged, of course, to the elite.

In communities that were probably not defined by any legal or institutional framework, participation in the group affairs and adhesion to the common values were of primary significance in the process of shaping the polis contour, in making the community. In these archaic cities behaviours allowed individuals to assert their status, whether social or political, and to have it acknowledged by other members of the group. In short, status performance was an essential part in the process of making a political community such as the archaic Greek polis.

\section{ACKNOWLEDGEMENTS}

I owe a particular debt to Roger Brock, whose invitation to Leeds in spring 2009 allowed me to start thinking on archaic citizenship thanks to a British Academy visiting fellowship. Sarah Morris and John Papadopoulos, who welcomed me to UCLA during spring 2011, spared me a lot of mistakes and greatly enhanced my

\footnotetext{
67 The debate between Murray and Schmitt-Pantel is broadly synthesized in this volume (chapter 1, section 5).
} 
thought. Although published after a long delay, this chapter has benefited from the writing of subsequent papers (some of them already published) in which I further explore various aspects of the question, but also thanks to the comments and critiques of other contributors to the volume, particularly Hans van Wees. As usual, any error remains mine, and I take full responsibility for the controversial or challenging opinions expressed here. Further thoughts on the subject will be presented in a forthcoming book, Construire la cité. 